\title{
Kinetic Parameters Analysis of Liver and Kidney Catalase Under the Influence of Cadmium (Cd) and Mercury $(\mathrm{Hg})$ In Vitro
}

Ellsa Anggun Karantika ${ }^{1}$, Supianur ${ }^{1}$, Edyson $^{2}$, Eko Suhartono ${ }^{2 *}$

\author{
${ }^{1}$ Medical Education Program, Faculty of Medicine, University of Lambung Mangkurat, Banjarmasin, Indonesia \\ ${ }^{2}$ Medical Chemistry and Biochemistry Department, Faculty of Medicine, University of Lambung Mangkurat, Banjarmasin, Indonesia
}

\section{ABSTRACT}

Cadmium $(\mathrm{Cd})$ and mercury $(\mathrm{Hg})$ are toxic metals that affect human organs function, including liver and kidney. This toxic activity is because the heavy metal could induce oxidative stress and interfere antioxidant activities, including catalase (CAT). The present study was aims to evaluate the effect of $\mathrm{Cd}$ and $\mathrm{Hg}$ to liver and kidney CAT kinetic parameters in vitro. In this experiment, liver and kidney were taken from male rats (Rattus novergicus). Sample the homogenized and divided into three groups with; T0 served as control which contains liver or kidney homogenate $+\mathrm{H}_{2} \mathrm{O}_{2}$, T1 which contains liver or kidney homogenate $+\mathrm{H}_{2} \mathrm{O}_{2}+0.03 \mathrm{mg} / \mathrm{L} \mathrm{CdSO}$; and T2 which contains liver or kidney homogenate $+\mathrm{H}_{2} \mathrm{O}_{2}+1 \mathrm{mg} / \mathrm{L} \mathrm{Hg}$. Solutions then incubated at $37^{\circ} \mathrm{C}$ for 1 hour and then was prepared for CAT activity measurement. The CAT activity was measured using spectrophotometer at $240 \mathrm{~nm}$. For measuring the kinetic parameters, different concentration of $\mathrm{H}_{2} \mathrm{O}_{2}$ were used. The kinetics parameters ( $\mathrm{Km}$ and $\mathrm{Vmax}$ ) were calculated using Lineweaver-Burk plot. The results shows that $\mathrm{Cd}$ and $\mathrm{Hg}$ could decrease the affinity of $\mathrm{CAT}-\mathrm{H}_{2} \mathrm{O}_{2}$ complex which expressed by the higher $\mathrm{Km}$ and Vmax values. Also from the results, Cd has better activity to decreased the affinity of CAT- $\mathrm{H}_{2} \mathrm{O}_{2}$ complex than $\mathrm{Hg}$. From this results, it can be concluded that $\mathrm{Cd}$ and $\mathrm{Hg}$ treatments could inhibit CAT activity in liver and kidney in vitro.

Keywords: Cadmium (Cd), catalase, kinetic parameters, mercury $(\mathrm{Hg})$

\section{INTRODUCTION}

Heavy metal such as $\mathrm{Cd}$ and $\mathrm{Hg}$ are toxic metals that are widespread in the environment $[1,2]$. These metals can occur as a results from natural, anthropogenic, and human sources $[2,3]$. These heavy metals are not biodegradable, so as consequences these can accumulate in living organisms [4]. Because of the nature of heavy metals tend to accumulate in living organisms, these metals can enter the food chain to humans [5].

Human exposure can cause many various effects to human organs, especially kidney and liver $[6,7]$. The previous study had shown that chronic exposure to $\mathrm{Cd}$ could induce kidney damaged, manifested by proteinuria, glucosuria, aminoaciduria, and phosphaturia [8]. The Cd also lead to a liver damaged [9], both in acute and chronic exposure. Many studies has well docu-

\section{${ }^{*}$ Corresponding author:}

Eko Suhartono

Medical Chemistry and Biochemistry Department, Faculty of Medicine, University of Lambung Mangkurat

Jalan Brigjen H. Hasan Basri, Banjarmasin 75117, Indonesia

E-mail address: ekoantioxidant@gmail.com mented that $\mathrm{Cd}$ exposure could cause the swelling, necrosis, and degeneration of hepatocytes [10]. Besides $\mathrm{Cd}, \mathrm{Hg}$ also well documented to induced liver and kidney damaged. The previous study had shown that $\mathrm{Hg}$ exposure will lead to kidney and liver cells necrosis $[11,12]$.

The basic mechanism of $\mathrm{Cd}$ and $\mathrm{Hg}$ toxicity is an activity to induce oxidative stress [13]. $\mathrm{Cd}$ and $\mathrm{Hg}$ also impair antioxidant defenses. These antioxidant defenses involving thiol-containing antioxidants and enzymes, including CAT $[14,15]$.

CAT is a heme-containing enzyme and found in almost all aerobically respiring organisms. CAT is an intracellular enzyme that can be found in all tissues and organs. The highest CAT concentrations are found in erythrocytes, liver, and kidney [16]. The main function of CAT catalyzes the conversion of hydrogen peroxide

\section{How to cite:}

Karantika EA, Supianur, Edyson, Suhartono E (2016) Kinetic parameters analysis of liver and kidney catalase under the influence of cadmium $(\mathrm{Cd})$ and mercury $(\mathrm{Hg})$ in vitro. J. Trop. Life. Science 6 (2): $65-68$. 
to molecular oxygen and water [17].

Although many researches in the interaction between these heavy metals ( $\mathrm{Cd}$ and $\mathrm{Hg}$ ) and the activity of CAT has well documented, but still the kinetics of CAT by the presence of both $\mathrm{Cd}$ and $\mathrm{Hg}$ has not been explored fully. Since CAT has a great function to maintain the cell function, especially in liver and kidney, investigation of the effect of $\mathrm{Cd}$ and $\mathrm{Hg}$ in CAT kinetic parameters seems to be importance. Therefore, in this study, we try to investigate the kinetics parameters of CAT with the presence of $\mathrm{Cd}$ and $\mathrm{Hg}$ in liver and kidney in vitro.

\section{MATERIALS AND METHODS}

\section{Animals and homogenate preparation}

Male rats (Rattus novergicus) weighing 200-250 gram with 2-3 months old were obtained from the Abadi Jaya farm at Yogyakarta, Indonesia, in healthy condition. The experiment was approved by the Ethical Committee from the University of Lambung Mangkurat. Animals were fed under standard conditions and acclimatized with a 12 hours light/dark cycle. The animals were sacrificed by surgical procedure. The livers and kidneys were removed. Then, the both organs homogenized in phosphate buffer saline ( $\mathrm{pH}$ 7.0). Then, each of homogenate was used for in vitro experimental models.

\section{Experimental models}

Samples was divided into 3 groups (1 control group and 2 treatment groups). Control: Homogenate + $\mathrm{H}_{2} \mathrm{O}_{2}$, T1: Homogenate $+\mathrm{H}_{2} \mathrm{O}_{2}+0.03 \mathrm{mg} / \mathrm{L} \mathrm{CdSO}$; and T2: Homogenate $+\mathrm{H}_{2} \mathrm{O}_{2}+1 \mathrm{mg} / \mathrm{L} \mathrm{Hg}$. Each solution then incubated at $37^{\circ} \mathrm{C}$ for 1 hour.

\section{Catalase activity measurements}

The CAT activity was measured by the method of Aebi [18], using spectrophotometer at $240 \mathrm{~nm}$. The activity defined as mmol of $\mathrm{H}_{2} \mathrm{O}_{2}$ consumed per minute, in $50 \mathrm{mM}$ phosphate buffer, $\mathrm{pH}$ 7.0.

\section{Catalase kinetic parameter measurements}

Kinetic parameters were determined by using five different concentrations of the substrate, $\mathrm{H}_{2} \mathrm{O} 2$. The substrate concentrations are $6.25,12.5,25$, and $50 \mathrm{mM}$ of $\mathrm{H}_{2} \mathrm{O}_{2}$. The kinetic parameters, Vmax, and $\mathrm{Km}$, were determined using the Lineweaver-Burk version of the Michaelis-Menten equation [19], as follows:

$$
\frac{1}{V}=\frac{k m}{V \max } \times \frac{1}{[S]}+\frac{1}{V \max }
$$

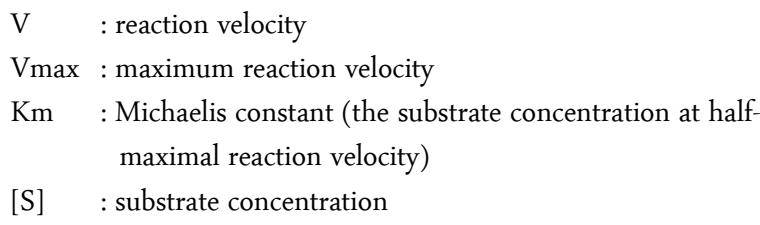

\section{RESULTS AND DISCUSSION}

In this present study, the kinetic parameters of liver and kidney CAT with the presence of $\mathrm{Cd}$ and $\mathrm{Hg}$ were investigated. The result shows in figure 1 for liver CAT, figure 2 for kidney CAT, and table 1 for $\mathrm{Km}$ and Vmax of both liver and kidney CAT in the group of treatments.

Figure 1 and 2 represent the Lineweaver-Burk plot of liver and kidney CAT respectively. From that plot, kinetic parameters $\mathrm{Km}$ and Vmax for liver and kidney CAT was calculated and presented in Table 1. Results revealed $\mathrm{Km}$ and Vmax values seems to be higher in $\mathrm{T} 1$ and T2 groups, in comparison with T0 group. Results of this present study also show that the highest $\mathrm{Km}$ and Vmax values are in T1 group (Table 1).

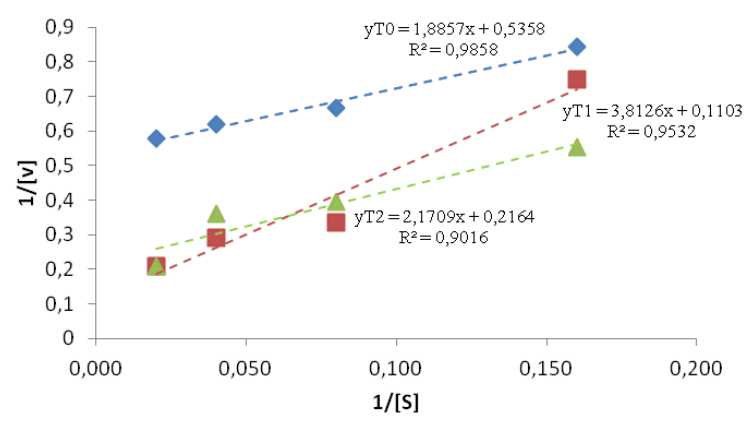

Figure 1. The Lineweaver-Burk plot for liver catalase. $\diamond$ : Control (T0); $\square$ Cd group (T1); $\wedge$ : Hg group (T2)

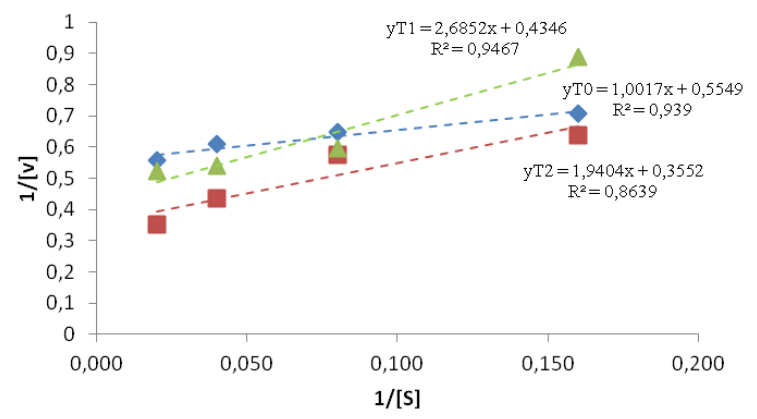

Figure 2. The Lineweaver-Burk plot for kidney catalase. $\diamond$ : Control (T0); $\mathbf{~ : ~ C d ~ g r o u p ~ ( T 1 ) ; ~} \mathbf{A}: \operatorname{Hg}$ group (T2) 
Table 1. Kinetic parameters and coefficient correlation for liver and kidney catalase in different group of treatments

\begin{tabular}{ccccccc}
\hline \multirow{2}{*}{ Groups } & \multicolumn{6}{c}{ Organs } \\
\cline { 2 - 7 } & \multicolumn{3}{c}{ Liver } & \multicolumn{5}{c}{ Kidney } \\
\cline { 2 - 7 } & Km & Vmax & $r$ & $K m$ & Vmax & $r$ \\
\hline T0 & 3.530 & 1868 & 0.993 & 1.804 & 1.802 & 0.969 \\
T1 & 34.579 & 9.066 & 0.996 & 5.470 & 2.817 & 0.973 \\
T2 & 10.041 & 4624 & 0.950 & 6.186 & 2.302 & 929 \\
\hline
\end{tabular}

Vmax and $\mathrm{Km}$ values reflect the catalytic and substrate binding ability of an enzyme, respectively. The smaller $\mathrm{Km}$ value represents, the greater affinity of enzyme-substrate complex. This means the enzyme can to catalyze the reaction to formed the product [20-21].

From the results suggest, with the presence of $\mathrm{Cd}$ and $\mathrm{Hg}, \mathrm{Km}$ and $\mathrm{Vmax}$ values are increase in both of organs. This suggests that $\mathrm{Cd}$ and $\mathrm{Hg}$ decrease the affinity between enzyme substrate. This means the presence of $\mathrm{Cd}$ and $\mathrm{Hg}$ decrease the affinity between CAT- $\mathrm{H}_{2} \mathrm{O}_{2}$ complex. The enzyme in not able to catalyze the reaction. $\mathrm{Cd}$ and $\mathrm{Hg}$ inhibit the CAT activity both in liver and kidney homogenate.

Results of this present study also show that Cd has a greater proportion to increase the $\mathrm{Km}$ and $\mathrm{Vmax}$ of liver CAT than $\mathrm{Hg}$. Interestingly, the opposite results showed in the $\mathrm{Km}$ of kidney CAT. In kidney CAT, $\mathrm{Km}$ values for the presence of $\mathrm{Hg}$ seems higher than with the presence of $\mathrm{Cd}$. This suggests, Cd has more inhibition activity in liver CAT, and $\mathrm{Hg}$ shows more in kidney CAT.

The presence of these both heavy metal, $\mathrm{Cd}$, and $\mathrm{Hg}$, will be able to inhibits the CAT activity in liver and kidney. The inhibition of CAT by $\mathrm{Cd}$ and $\mathrm{Hg}$ is based on these two basic mechanisms, as follow:

1. Heavy metals including $\mathrm{Cd}$ and $\mathrm{Hg}$ can make a bond formation with the sulfhydryl groups $(-\mathrm{SH})$ of cysteine. The presence of metals can replace the hydrogen atoms - $\mathrm{SH}$ groups, thus inhibited the activity of enzymes [22-23].

2. $\mathrm{Hg}$ and $\mathrm{Cd}$ can replace a metal ion in the body's metalloenzyme [24]. It is well known that CAT is metalloenzyme, that contain four subunits and each subunit contains 1 Fe-protoheme IX [25]. The presence of $\mathrm{Cd}$ and $\mathrm{Hg}$ can replace $\mathrm{Fe}$ in CAT subunit leading to inactivation of CAT [24].

\section{CONCLUSION}

From this present study, it can be concluded that $\mathrm{Cd}$ and $\mathrm{Hg}$ could increase the $\mathrm{Km}$ and Vmax values of liver and kidney CAT. It seems $\mathrm{Cd}$ and $\mathrm{Hg}$ inhibit the activity of CAT by decreased the affinity of CAT- $\mathrm{H}_{2} \mathrm{O}_{2}$ complex.

\section{ACKNOWLEDGMENT}

Authors are thankful to Iskandar, dr. from Research Unit Mutiara Bunda Mother and Child Hospital, Martapura, South Kalimantan Indonesian, for his support and encouragement during the process of writing this research.

\section{REFERENCES}

1. Aflanie I, Muhyi R, Suhartono E (2015) Effect of heavy metal on malondialdehyde and advanced oxidation protein produtcs concentration: A focus on arsenic, cadmium, and mercury. JOMB. 4 (4): 332-337. doi: 10.12720/jomb.4.4.332-337.

2. Prokopowicz A, Pawlas N, Ochota P et al (2014) Blood levels of lead, cadmium, and mercury in healthy women in their 50s in urban area of poland: A pilot study. Pol J Envriron Stud. 23 (1): 167-175.

3. Olmedo P, Pla A, Hernandez AF et al (2013) Determination of toxic elements (mercury, cadmium, lead, tin and arsenic) in fish and shellfish samples. Risk assessment for the consumers. Environt Int. 59: 63-72.

4. El Said AG, Badawy NA, Garamon SE (2012) Adsorption of cadmium (II) and mercury (II) onto natural adsorbent rice husk ash (RHA) from aqueous solutions: Study in single and binary system. IJC. 1: 58-68.

5. Ekpo KE, Asia IO, Amayo KO et al (2008) Determination of lead, cadmium and mercury in surrounding water and organs of some species of fish from Ikpoba river in Benin city, Nigeria. Int J Phys Sci. 3 (11): 289-292.

6. Morais S, Costa FG, Pereira ML (2012) Heavy metals and human health, Environmental Health - Emerging Issues and Practice, Prof. Jacques Oosthuizen (Ed.). InTech ISBN: 978-953-307-854-0.

7. Arroyo VS, Flores KM, Ortiz LB et al (2012) Liver and cadmium toxicity. J Drug Metab Toxicol. S5: 001. doi:10.4172/2157-7609.S5-001.

8. Karimi MM, Sani MJ, Mahmudabadi AZ et al (2012) Effffect of acute toxicity of cadmium in mice kidney cells. IJT. 6 (18): 691-698.

9. Suhartono E, Triawanti, Yunanto A et al (2013) Chronic cadmium hepatooxidative in rats: treatment with haruan fish (Channa striata) extract. APBEE Procedia. 5: 441-445.

10. Wibowo A, Rahaju FA, Iskandar et al (2014) The role of urinary cadmium on liver function and erythrocytes cell 
count in pregnancy. IJBBB. 4 (4): 224-228. doi: 10.7763/IJBBB.2014.V4.344.

11. Soderland P, Lovekar S, Weiner DE et al (2010) Chronic kidney disease associated with environmental toxins and exposures. Adv Chronic Kidney D. 17 (3): 254-264.

12. Hussein HK, Abu-Zinadah OA, El Rabey HA et al (2013) Estimation of some heavy metals in polluted well water and mercury accumulation in broiler organs. Braz Arch Biol Technol. 56 (5): 767-776.

13. Suhartono E, Triawanti, Leksono AS et al (2014) Oxidative stress and kidney glycation in rats exposed cadmium. IJCEA. 5 (6): 497-501. doi: 10.7763/IJCEA.2014.V5.435.

14. Sevcikova M, Modra H, Slaninova A et al (2011) Metals as a cause of oxidative stress in fish: A review. Vet Med Czeczh. 56 (11): 537-546.

15. Valko M, Morris H, Cronin MTD (2005) Metals, toxicity and oxidative stress. Curr Med Chem. 12: 1161-1208.

16. Kodydkova J, Vavrova L, Kocik M et al (2014) Human catalase, its polymorphism, regulation, and changes of its activity in different diseases. Folia Biol-Prague. 60: 153167.

17. Glorieux C, Auquier J, Dejeans N et al (2014) Catalase expression in MCF-7 breast cancer cells is mainly controlled by PI3K/Akt/mTor signaling pathway. Biochem Pharmacol. 89: 217-223.

18. Aksoy Y, Balk M, Ogus IH et al (2004) The mechanism of inhibition of human erythrocyte catalase by Azide. Turk J
Biol. 28: 65-70.

19. Shang ZC, Zhang LL, Wu ZJ et al (2012) The activity and kinetic parameters of oxidoreductases in phaeozem in response to long-term fertiliser management. J Soil Sci Plant Nutr. 12 (3): 605-615.

20. Choy D, Lee D, Ma J et al(2014) Phthalate confers protection against UV-A irradiation but is an uncompetitive inhibitor of bovine catalase at high concentrations. JEMI. 18: 82-86.

21. Schnell S (2014) Validity of the Michaelis-Menten equation - steady-state or reactant stationary assumption: that is the question. FEBS Journal. 281: 464-472. doi:10.1111/febs.12564.

22. Sharma R (2012) Enzyme inhibition: mechanism and scope, enzyme inhbition and bioapplications. Prof Rakesh Sharma (Ed.). InTech. ISBN: 978-953-51-0585-5.

23. Jonsson CM, Aoyama H (2009) Extraction, partial characterization and susceptibility to $\mathrm{Hg}^{2+}$ of acid phosphatase from the microalgae Pseudokirchneriella subcapitata. Sci Agric (Piracicaba, Braz). 66 (5): 634-642.

24. Duruibe JO, Ogwuegbu MOC, Egwurugwu JN (2007) Heavy metal pollution and human biotoxic effects. Int $\mathrm{J}$ Phys Sci. 2 (5): 112-118.

25. Aruldoss V, Kalaichelvan PT (2014) Production of catalase by solid state fermentation using different agro and fruit peel wastes as substrates. Journal of Modern Biotechnology. 3 (1): 8-13. 
